\title{
Behavioral Accounting of Amir and Takmir Sunan Ampel Surabaya on Financial Reporting
}

\author{
Aprilya Dwi Yandari and Erina Sudaryati \\ Department of Accounting, Airlangga University, Surabaya, Indonesia \\ aprilyadwiyandari09@gmail.com, erina.sudaryati@feb.unair.ac.id
}

Keywords: $\quad$ SFAS No. 45 year 2011, sunan ampel, transparency, accountability.

\begin{abstract}
This research used qualitative research with descriptive approach. The data used secondary data, with data collection techniques using observation, and documentation. The purpose of this study is to review, analyze how the amir and takmil behavior forms in financial reporting on Sunan Ampel for accountability to the community in the form of transparency and accountability. Previously religious life seemed to be another dimension that does not require transparency and accountability directly in the form of accounting reporting. Structured financial statements as set out in SFAS No. 45 year 2011 can be used as a guide to prepare financial statements so that the financial statements produced accountable and more transparent. Providing information that is transparent and accountable, takmir has encouraged the community to participate in maintaining and maintaining the beauty of the area, because they seem to share in it. Given this form of responsibility, it can limit the unacceptable behavior of takmir and amil, with the fear that they will convey information that is not actually happening due to its own interests. The existence of good management, then the funds can be useful to reduce the social gap, where the less fortunate people can feel the benefits of the donation. It will cause friendship among fellow human beings become more intense, so that Islam really become rahmatan lil alamin or grace for the universe.
\end{abstract}

\section{$1-$ INTRODUCTION}

Indonesia has a new cultural diversity that is the result of the acculturation of indigenous Indonesian culture, which has a major influence from Hinduism with Islam that goes to Indonesia. This can cause the people of Indonesia to now greatly respect the Wali Allah. And now, one of the honorable efforts that the community can make to privilege its grave. They assume that the Wali Allah has karomah value because of his glory in spreading the religion of Islam so according to them whoever praying around the tomb of the Wali Allah will get his karomah. One of the guardians of God who plays a major role in the spread of Islam in Surabaya is Sunan Ampel. In a certain time or month, many Muslims who together visit the maqam of the guardian, either with groups or individuals. In his visit, many Muslims who also contributed to the infaq or sodaqoh either to the area manager or through a small box that already exists.

Donations in the form of infaq and sodaqoh from the community we can value as one source of income for managers or communities around the area. However, in our opinion, the fund management is not maximal because the public does not know how the form of responsible management is done by the manager of the area and whether there is transparency for every transaction made by the manager regarding the needs that occur within the scope. In fact, the high level of uncertainty and environmental instability faced by various organizations, it needs a good planning system in any case. Thus, the role of accounting in terms of financial management of an organization even more realized by various parties, both profit oriented and non-profit organizations.

Jusuf (2005) states that non-profit organizations are non-profit organizations such as religious organizations, foundations or educational institutions. As the study conducted by Andarsari (2016) relates to the financial reports of non-profit organizations, especially in the mosques which state that mosque institutions in their financial management require good accounting implementation as a form of accountability to donors and the surrounding community who become mosque worshipers. Structured financial statements 
as set out in SFAS No. 45 year 2011 can be used as a guide to prepare financial statements so that the financial statements produced accountable and more transparent.

So, the process of recording the financial of the mosque or like Ampel burial area usually only includes cash receipts and expenses alone without showing the amount of assets owned by the area and how much its value, so many cases of loss assets due to the weakness of the financial reporting system. The application of a sound financial system will provide an appropriate answer to the public's doubt about the organization of the mosque, takmir, and its administrators.

Therefore, in the presence of a motivational drive to begin to improve the accountability system undertaken by the Ampel area management agency, we try to take the issue of how the accountability process exists within the area. Whether, the responsibility is transparent or not. Because the role of transparency is very important in an organization so as not to generate opinions outside the interests that we expected.

\section{THEORETICAL BASES}

\subsection{Definition of Infaq / Shadaqah}

The definition of infaq, according to Cholid (1993: 5 ) in Suyitno and Abdushomad (2005) said infaq can mean donate or provide sustenance or spend something to others based on sincerity and for God alone. From the Qur'an, the infaq command contains two dimensions, namely: 1) infaq is obliged jointly; and 2) voluntary infaq sunna.

Shadaqah, shadaqah comes from the word shadaqah which means true and can be understood by giving or giving something to others. In this concept, shadaqah is a manifestation of faith and taqwa for a person, meaning a person who likes to give charity is a person who is true to his or her faith. (Suyitno and Abdushomad, 2005)

\subsection{Recognition, Measurement and Presentation of Zakat, Infaq / Shadaqah in PSAK No. 109}

Initial Recognition of Zakat, that IAI (2012) of zakat is recognized when cash or other assets are received. Then Zakat is recognized as a zakat fund enhancer:

- If accepted cash form then,

- If received in non-refundable form at the fair value of the noncash assets,
Measurement after Zakat initial recognition, in IAI (2012) the measurement of zakat is explained that if there is a decrease in the value of zakah assets, the amount of the loss is treated as a deduction of zakat fund or amil fund deduction depending on the cause of the loss. And the impairment of zakat is recognized as:

- Zakat deduction of funds, if not caused by negligence amil,

- Losses and losses amil funds, if caused by negligence amil,

The distribution of zakat, IAI (2012) explains that zakat channelled to mustahiq is recognized as a deduction of zakat funds for:

- Amount delivered, if in cash,

- The carrying amount, if in the form of noncash assets,

Measurement after initial recognition infaq/shadaqah, infaq/alms received can be cash or non-cash assets. Noncash assets may be current assets or non-current assets. Non-current assets received by amil and mandated for management are valued at fair value on receipt and recognized as non-current assets of infaq/alms. Depreciation of the asset is treated as a deduction of infaq/tied funds if the use or management of the asset is determined by the giver IAI (2012).

Current noncash assets are valued at cost, while noncurrent assets are valued at fair value in accordance with the relevant PSAK. Impairment of infaq/alms donated assets is recognized as:

- Reducing infaq / alms funds, if it happens not caused by negligence amil,

- Losses and losses amil funds, if caused by negligence amil,

Presentation of Zakat, Infaq/Shadaqah, according to IAI (2012) that amil presents zakat funds, infaq/alms funds, amil funds, and nonhalal funds separately in the balance sheet (financial position report).

\section{PREVIOUS RESEARCH}

In the description of the problems we observed, we have similar research related to previous studies. But in our research, we did different research on the Ampel area object by looking at the point of view of the management of the funeral and can also be linked to the management of the mosque. The following research is related to PSAK 109, including:

Istutik (2013) examines related to the implementation analysis of zakat accounting and 
infaq/alms (PSAK109) at amil zakat institution in Malang. This research uses descriptive qualitative research conducted in five places, namely LAZIS Sabilillah, Baitul Maal Hidayatullah (BMH), AlFalah Social Fund Foundation (YDSF), LAZISMU, and LAZIS Baitul Ummah. In this study resulted that amil institutions have not applied ZIS accounting standard (PSAK 109) for the preparation of its financial statements. On the other hand, financial accountability still limited to reports of cash receipts and disbursements. Introduction and moreover understanding of managers of amil institutions against PSAK 109 was still very less. It requires the involvement of universities, professional organizations, or the ILZNAS to provide training on PSAK 109. With the education level of the majority of universities managers, training will be able to immediately improve their understanding of PSAK 109.

Shahnaz (2016) examines the implementation of PSAK 109 regarding the accounting financial reporting of zakat, infaq/alms to BAZNAS of North Sulawesi Province. In this study used the analytical method used was descriptive qualitative. The result of this research was BAZNAS Provinsi SULUT not yet prepare financial report according to PSAK No.109. The financial statements of BAZNAS were in the form of income report and fund distribution, so that financial reporting, fund change report, asset change report, cash flow statement and notes to financial statement are required.

Hermawan and Astriana (2010) examine related to zakat accounting and efforts to increase transparency and accountability of amil zakat institutions. In this study resulted that financial data in the form of financial statements can be presented with complete as the theory revealed, with the presentation of financial statements that are simple and accountable. The form of transparency and accountability of LAZNAS "XYZ" to stakeholders of this institution is reflected in the financial statements presented either through data received by the researcher or data that can be opened directly on the official website, although the financial reporting form in the official site of LAZNAS "XYZ" certain period.

Andarsari (2016) examines the financial statements of non-profit organizations (mosque institutions). This study resulted in the existence of structured financial statements as set out in SFAS No. 45 year 2011 can be used as a guide to prepare financial statements so that the financial statements produced accountable and more transparent. This was also the answer to the distrust of people who are wondering about the mosque's financial statements, which were usually very simple and not detailed.

Habib (2016) examines in relation to the principle of zakat, infaq, and shadaqah accounting based SFAS 109. In this study was a literature study that emphasis was placed on the use of secondary data. This study found that most BAZIS in making financial statements were not guided by PSAK 109, that was many still use simple financial reporting with cash basic method, where the recording of all transactions was only done when issuing and receiving cash.

\section{RESEARCH METODOLOGY}

In writing this article using qualitative research methods, by using data collection method of literature study and the type of seconder data in the form of the results of previous studies by obtaining the data from interviews to the parties it and by obtaining data observational. The literature related data were collected and analyzed by reviewing how the researchers interpreted in providing feedback on each of the existing problems and in providing solution solutions on any issues related to this article.

\section{RESULTS AND DISCUSSION}

All activities of both public and private institutions are always required to be transparent and accountable. Religious life seems to be another dimension that does not require transparency and accountability directly in the form of accounting reporting. Accounting is shaped by its environment through complex social interactions, it can also turn to affect its environment. Even though traditional views see accounting as being constructed through social interaction as a result of social, economic, and political events, there is another approach to accounting forming its environment with social interaction (socially constructing). This proves that accounting is not a form of value-free science and practice, but on the contrary it is a discipline and practice and very loaded with value.

Transparency needs to be done by amir or takmir management of zakat or infaq in mosque. This has been discussed in Al-Quran Surah Al-Baqarah verse 282, states:

"O ye who believe! When ye contract a debt for a fixed term, record it in writing. Let a scribe 
record it in writing between you in (terms of) equity. No scribe should refuse to write as Allah hath taught him, so let him write, and let him who incurreth the debt dictates, and let him observe his duty to Allah his Lord and diminish naught thereof. But if he who oweth the debt is of low understanding, or weak, or unable himself to dictate, then let the guardian of his interests dictate in (terms of) equity. And call to witness, from among your men, two witnesses. And if two men be not (at hand) then a man and two women, of such as ye approve as witnesses, so that if the one erreth (through forgetfulness) the other will remember. And the witnesses must not refuse when they are summoned. Be not averse to writing down (the contract) whether it be small or great, with (record of) the term thereof. That is more equitable in the sight of Allah and surer for testimony, and the best way of avoiding doubt between you; save only in the case when it is actual merchandise which ye transfer among yourselves from hand to hand. In that case it is no sin for you if ye write it not. And have witnesses when ye sell one to another, and let no harm be done to scribe or witness. If ye do (harm to them) lo! it is a sin in you. Observe your duty to Allah. Allah is teaching you. And Allah is knower of all things. The above verse is the longest verse in the Qur'an and clearly contains the order of recording practice in economic transactions or accounting transactions. This verse is the most explicit verse discussing accounting practice, taking note of transparently because recording is part of the main function of accounting ".

Accountability is demonstrated by the actions of individuals and organizations, not only through reporting and disclosure requirements, but also in their responsibility to the public in terms of organizational and performance values (Ebrahim, 2003). Public accountability is the responsibility of the recipient of responsibility for managing resources, reporting and disclosing all activities and activities related to the use of public resources to the principal. Amil or takmir need to prioritize by disclosing all activities and activities related to the management of funds undertaken. This is because accountability also means an obligation to account for what a person has done or does not do. Responsibility is one of the central teachings of religion. That God is All-Just, then everyone will be responsible for his actions, no matter how small it is, and will get a worthy reply. Replies can be received later in the hereafter, or now in the world, or even both, rewarded in the world and in the Hereafter. This is in accordance with what has been discussed in verses of Al-Quran in $\mathrm{Al}$ Mudatstsir verse 38 states:

"Each person is responsible for what he has done"

Behavior of responsibility must be applied wherever we are because it is a commendable character, therefore we are responsible for any form whatever we do, whether it is good deeds or not. Being responsible means that we too have been honest about both ourselves and others. By explaining the verse, we hope that amil and takmir have an awareness of themselves to be fully responsible for the management of the funds obtained from the community, so that management can be maximized again.

In addition, by disclosing accountable and transparent information, amil and takmir will gain greater public trust, so that the community will be encouraged to participate actively in the activities that are held. The community can also be a monthly donor whose funds can be of great benefit to the management of mosques and tombs in the Sunan Ampel complex. By providing transparent and accountable information, takmir has encouraged the community to participate in maintaining and maintaining the beauty of the area, as they seem to share the area.

Then, in the presence of good management, the funds will also be useful to reduce social inequality, where the less fortunate people can also benefit from the donation. By reducing the gap, it is expected to increase the affection between the rich and the poor, because poor people feel cared for and then they will be helped financially. Not only for the poor, but good fund management will also be useful for those in need, such as the victims of natural disasters without paying attention to their background and religion. The existence of this will cause friendship among fellow human beings become increasingly tight, so that Islam really become rahmatan lil alamin or grace for the universe.

\section{CONCLUSIONS}

Behavioral responsibility should be applied wherever us because it is a commendable trait. We are responsible for all the things we do, whether they are good deeds or not. Amil and takmir are expected to have an awareness of themselves to take full responsibility for the management of funds obtained from the community, so that management can be maximized again. Given the form of responsibility 
to the donor community, it can limit the unacceptable behavior of takmir and amil. Where there is a concern that they will convey information that is not actually happening because of their own interests. In addition, with good management, the funds are also beneficial to reduce social inequality, where the less fortunate people can also benefit from the donation. So, with the reduction of the gap is expected to increase awareness among the rich and poor, because the poor people feel cared for. And then they will be helped from the financial side. Not only for the poor, but good fund management will also be useful for those in need, such as the victims of natural disasters without paying attention to their background and religion. The existence of this will cause friendship among fellow human beings become increasingly tight, so that Islam really become rahmatan lil alamin or grace for the universe.

\section{REFERENCES}

Al-Qur'an dan Terjemahannya, 1976. Departemen Agama RI, Bumi Restu. Jakarta.

Andarsari, P. R., 2016. Laporan Keuangan Organisasi Niralaba (Lembaga Masjid). EKONIKA (Jurnal Ekonomi Universitas Kadiri), 1(2).

Ebrahim, A., 2003. Accountability in practice: Mechanisms for NGOs. World development, 31(5), 813-829.

Habib, A. A., 2016. The Principle Of zakat, Infaq, and Shadaqah Accounting Based SFAS 109. Journal of Accounting and Business Education, 1(1), 1-19.

Hermawan, S., Astriana, G., 2010. Akuntansi Zakat dan Upaya Peningkatan Transparansi dan Akuntanbilitas Lembaga Amil Zakat. Jurnal Ekonomi, 1(2), 34-42.

IAI, 2012. Pernyataan Standar Akuntansi Keuangan (PSAK) No. 109, Dewan Standar Akuntansi Keuangan Ikatan Akuntan Indonesia. Jakarta.

Istutik, I., 2013. Analisis Implementasi Akuntansi Zakat dan Infak/Sedekah (PSAK:109) Pada Lembaga Amil Zakat di Kota Malang. Jurnal Akuntansi Aktual, Vol.2, No. 1, 19-24.

Shahnaz, S., 2016. Penerapan PSAK No. 109 Tentang Pelaporan Keuangan Akuntansi Zakat, Infaq/Sedekah Pada Baznas Provinsi Sulawesi Utara. Jurnal Berkala Ilmiah Efisiensi, 16(1).

Suyitno, H. J., Abdushomad, A., 2005. Anatomi fiqh zakat, Pustaka Pelajar, cet. Yogyakarta. 